\title{
Catellibacterium aquatile sp. nov., isolated from fresh water, and emended description of the genus Catellibacterium Tanaka et al. 2004
}

Correspondence

Zhi-Pei Liu

liuzhp@sun.im.ac.cn

\author{
Ying Liu, ${ }^{1}$ Cheng-Jun $\mathrm{Xu}^{2}{ }^{2}$ Jia-Tong Jiang, ${ }^{1}$ Ying-Hao Liu, ${ }^{1}$ \\ Xue-Feng Song, ${ }^{2}$ Hao $\mathrm{Li}^{2}$ and Zhi-Pei Liu ${ }^{1}$ \\ ${ }^{1}$ State Key Laboratory of Microbial Resources, Institute of Microbiology, \\ Chinese Academy of Sciences, Beijing 100101, PR China
}
${ }^{2}$ Water Supply Company of Daqing Petroleum Administration, No. 49, Aiguo Road, Ranghulu District, Daqing 163453, PR China

\begin{abstract}
A Gram-negative, rod-shaped, non-pigmented, non-spore-forming bacterial strain that was motile by a single polar flagellum, designated $A 1-9^{\top}$, was isolated from Daqing reservoir in north-east China and its taxonomic position was studied using a polyphasic approach. Strain $A 1-9^{\top}$ was non-halophilic, strictly aerobic and heterotrophic and lacked carotenoids, internal membranes and genes for photosynthesis (puf genes). Strain $\mathrm{A} 1-9^{\top}$ grew at $10-40{ }^{\circ} \mathrm{C}$ (optimum, $25-30{ }^{\circ} \mathrm{C}$ ) and $\mathrm{pH}$ 5.5-9.0 (optimum, $\mathrm{pH} 6.0-6.5$ ) and tolerated up to $1.0 \% \mathrm{NaCl}(\mathrm{w} / \mathrm{v}$ ). Neither phototrophic nor fermentative growth was observed. The predominant ubiquinone was $\mathrm{Q}-10$ and the major fatty acid was $\mathrm{C}_{18: 1} \omega 7 \mathrm{c}(70 \%)$. The DNA G $+\mathrm{C}$ content was $64.4 \mathrm{~mol} \%\left(T_{\mathrm{m}}\right)$. Phylogenetic analyses based on the 16S rRNA gene sequence revealed that strain $A 1-9^{\top}$, together with

Catellibacterium nectariphilum AST4 ${ }^{\top}$, formed a deep line within the 'Rhodobacter clade' of the family Rhodobacteraceae and strain A1-9 $9^{\top}$ showed 94.2\% 16S rRNA gene sequence similarity to C. nectariphilum AST4 ${ }^{\top}$. On the basis of phenotypic, chemotaxonomic and phylogenetic data, strain $A 1-9^{\top}$ is considered to represent a novel species of the genus Catellibacterium, for which the name Catellibacterium aquatile sp. nov. is proposed. The type strain is $\mathrm{A} 1-9^{\top}$ (=CGMCC $1.7029^{\top}=$ NBRC $104254^{\top}$ ).
\end{abstract}

The genus Catellibacterium, belonging to the 'Rhodobacter clade' of the family Rhodobacteraceae of the class Alphaproteobacteria, was proposed by Tanaka et al. (2004). At the time of writing, the genus includes only one species, Catellibacterium nectariphilum, which was isolated from activated sludge and requires a diffusible compound from other bacterial cultures for vigorous growth (Tanaka et al., 2004). Since 2008, many novel bacteria belonging to 'Rhodobacter clade' have been isolated from various environments, such as Rhodobacter megalophilus from soil (Arunasri et al., 2008), Rhodobacter maris and Rhodobacter aestuarii from marine environments (Venkata Ramana et al., 2008, 2009), Rhodobacter ovatus from a polluted pond (Srinivas et al., 2008), Rhodovulum kholense from mud (Anil Kumar et al., 2008), Rhodovulum lacipunicei (Chakravarthy et al., 2009), Paracoccus halophilus from marine sediment (Liu et al., 2008), Paracoccus aestuarii from tidal-flat sediment (Roh et al., 2009),

The GenBank/EMBL/DDBJ accession number for the $16 \mathrm{~S}$ rRNA gene sequence of strain $A 1-9^{\top}$ is EU313813.

A transmission electron micrograph of cells of strain $A 1-9^{\top}$ is available as supplementary material with the online version of this paper.
Paracoccus saliphilus from a salt lake (Wang et al., 2009) and Rhodobaca barguzinensis from sediments of a soda lake (Boldareva et al., 2008). Their wide distribution and metabolic diversity (such as heterotrophic, phototrophic and chemically autotrophic metabolism) suggest that members of this clade may play important roles in various ecosystems, especially aquatic environments. In a survey of the bacterial diversity of Daqing reservoir in north-east China, a bacterial strain, designated $A 1-9^{\mathrm{T}}$, was obtained, and database comparisons (http://www.ncbi.nlm.nih.gov/) showed that it was related to members of the 'Rhodobacter clade', especially to members of the genus Catellibacterium (Tanaka et al., 2004). In this communication, we report the isolation and taxonomic characterization of this strain.

The sample was collected from Daqing reservoir [sample site GPS position $46^{\circ} 47^{\prime} 40.9^{\prime \prime} \mathrm{N} 125^{\circ} 06^{\prime} 46.9^{\prime \prime} \mathrm{E}$, depth $2.0 \mathrm{~m}, \mathrm{pH} 8.5,23{ }^{\circ} \mathrm{C}$, chemical oxygen demand (CODcr) $15 \mathrm{mg} \mathrm{l}^{-1}$, biological oxygen demand (BOD) $10 \mathrm{mg} \mathrm{l}^{-1}$, total nitrogen (TN) $0.8 \mathrm{mg} \mathrm{l}^{-1}$ and total phosphorus (TP) $\left.0.07 \mathrm{mg} \mathrm{l}^{-1}\right]$. For isolation of bacterial strains, the serially 10-fold diluted water sample was spread onto low-organic Luria-Bertani [LOLB, containing $1.0 \mathrm{~g}$ tryptone (Difco), 
$0.5 \mathrm{~g}$ yeast extract and $\left.10.0 \mathrm{~g} \mathrm{NaCl}^{-1} ; \mathrm{pH} 8.0\right]$ agar plates and incubated at $30{ }^{\circ} \mathrm{C}$ for 2 days. A bacterial strain, designated $\mathrm{A} 1-9^{\mathrm{T}}$, was obtained. Subcultures were performed using YP medium [per litre distilled water: $3.0 \mathrm{~g}$ tryptone (Difco), $3.0 \mathrm{~g}$ yeast extract (Difco), $0.5 \mathrm{~g}$ $\mathrm{MgSO}_{4} \cdot 7 \mathrm{H}_{2} \mathrm{O}, 0.3 \mathrm{~g} \mathrm{NaCl}, 15 \mathrm{~g}$ agar, $\mathrm{pH} 7.0$ ] or the strain was stored as glycerol stocks $\left(15 \%\right.$, w/v) at $-80{ }^{\circ} \mathrm{C}$.

Growth on several bacteriological media was tested: YP agar, R2A agar, trypticase soy agar (TSA; Difco), nutrient agar, Luria-Bertani (LB) agar and LOLB agar. Abundant growth was observed on YP agar, R2A agar and LOLB agar, but no growth was seen on the other media.

The Gram stain was performed as described by Gerhardt et al. (1994). Cell morphology was observed by phasecontrast microscopy and scanning electron microscopy (FEI QUANTA 200). Gliding motility was determined by the hanging drop method according to Dong \& Cai (2001) and flagellation was confirmed by transmission electron microscopy (H600; Hitachi) after negative staining with $1 \%(\mathrm{w} / \mathrm{v})$ phosphotungstic acid. Colony morphology was observed on YP agar. Catalase and oxidase activities, $\mathrm{H}_{2} \mathrm{~S}$ production and hydrolysis of casein, starch and Tweens 20 , 40, 60 and 80 were determined using standard methods (Cowan \& Steel, 1965; Bruns et al., 2001). Growth at 4, 10, $16,20,25,30,35,40$ and $45^{\circ} \mathrm{C}, \mathrm{pH}$ 5.0-9.5 (in increments of $0.5 \mathrm{pH}$ units) and $0,0.5,1.0,1.5,2.0,2.5,3.0 \% \mathrm{NaCl}$ was determined in YP liquid medium. Carbon source assimilation was determined using Biolog GN2 plates (MicroStation). Acid production from various substrates was determined using bioMérieux 50 CHB/E strips according to the manufacturer's instructions. The activity of enzymes was determined using the API ZYM system (bioMérieux) following the manufacturer's instructions. $C$. nectariphilum JCM $11959^{\mathrm{T}}$ was analysed in parallel. Other physiological tests were performed using the API 20NE system (bioMérieux) according to the manufacturer's instructions. Susceptibility to antibiotics was determined on YP agar plates using filter-paper discs (Beijing Pharmaceutical Company) containing various antibiotics as specified in the species description. All of the above tests were performed in triplicate.

The morphological, physiological and biochemical characteristics of strain $\mathrm{A} 1-9^{\mathrm{T}}$ are shown in Table 1 or are given in the genus and species descriptions. Strain A1- $9^{\mathrm{T}}$ was strictly aerobic and heterotrophic. Cells were Gram-negative, nonspore-forming rods, motile by a single polar flagellum, $0.5-$ $0.6 \mu \mathrm{m}$ wide and 1.0-1.6 $\mu \mathrm{m}$ long (Supplementary Fig. S1, available in IJSEM Online). Colonies on YP agar were transparent, smooth, circular and convex, 1-2 $\mathrm{mm}$ in diameter after incubation for 2 days at $30{ }^{\circ} \mathrm{C}$. Strain A1-9 ${ }^{\mathrm{T}}$

Table 1. Properties that differentiate strain $A 1-9^{\top}$ from C. nectariphilum JCM $11959^{\top}$

Data are from this study unless indicated. Both strains are positive for oxidase and catalase activities and oxidation of $\beta$-hydroxybutyrate, monomethyl succinate and DL-lactate. Both strains are negative for nitrate reduction, phototrophic growth, indole production, urease activity and hydrolysis of gelatin and arginine. In the API ZYM system, both strains are positive for esterase, esterase lipase, leucine arylamidase and acid phosphatase and negative for lipase, cystine arylamidase, trypsin, chymotrypsin, $\alpha$-galactosidase, $\beta$-glucuronidase, $N$-acetyl- $\beta$-glucosaminidase, $\alpha$ mannosidase and $\alpha$-fucosidase. + , Positive; w, weakly positive; - , negative.

\begin{tabular}{|c|c|c|}
\hline Characteristic & A1-9 $9^{T}$ & $\begin{array}{c}\text { C. nectariphilum JCM } \\
11959^{\mathrm{T}}\end{array}$ \\
\hline Requirement for diffusible compounds from other bacterial cultures for vigorous growth & - & $+^{*}$ \\
\hline $\mathrm{NaCl}$ tolerance $(\%, \mathrm{w} / \mathrm{v})$ & 1.0 & 2.5 \\
\hline \multicolumn{3}{|l|}{ Temperature for growth $\left({ }^{\circ} \mathrm{C}\right)$} \\
\hline Range & $10-40$ & $20-37$ \\
\hline \multicolumn{3}{|l|}{$\mathrm{pH}$ for growth } \\
\hline Range & $5.5-9.0$ & $6.0-8.0$ \\
\hline Optimum & $6.0-6.5$ & $6.5-7.5$ \\
\hline \multicolumn{3}{|l|}{ Utilization of: } \\
\hline L-Arabinose, L-alanyl glycine & + & - \\
\hline Glycogen, Tween 80 , methyl pyruvate, $\alpha$-ketoglutarate & - & + \\
\hline$\beta$-Galactosidase, $\alpha$-glucosidase, $\beta$-glucosidase & + & - \\
\hline DNA G $+\mathrm{C}$ content $(\mathrm{mol} \%)$ & 64.4 & $64.5^{*}$ \\
\hline
\end{tabular}

${ }^{\star}$ Data taken from Tanaka et al. (2004). 
grew at $10-40{ }^{\circ} \mathrm{C}$ (optimum, $25-30{ }^{\circ} \mathrm{C}$ ) and $\mathrm{pH} 5.5-9.0$ (optimum, $\mathrm{pH}$ 6.0-6.5). $\mathrm{NaCl}$ was not required for growth; strain A1 $-9^{\mathrm{T}}$ tolerated up to $1.0 \%(\mathrm{w} / \mathrm{v}) \mathrm{NaCl}$.

Phototrophic growth under microaerobic and anaerobic conditions was determined after incubation in an Oxoid AnaeroGen system using the medium of Pfennig \& Trüper (1974) and as detailed by Imhoff \& Caumette (2004), mainly including the detection of an internal membrane system and photosynthetic pigments and utilization of some carbon sources. In vivo pigment-absorption spectrum analysis was examined as described by Yoon et al. (2004) using a Unico UV-2802H spectrophotometer (Shanghai Optical Company). Detection of puf genes was performed by a PCR-amplification method and 13 pairs of primers as described by Nagashima et al. (1997); Rhodobacter capsulatus JCM $21090^{\mathrm{T}}$ was used as a positive control. The PCR products were then sequenced to confirm the correct amplification.

Strain A1-9 ${ }^{\mathrm{T}}$ was unable to grow photoautotrophically [anaerobically in the light, with thiosulfate $(0.1 \% \mathrm{w} / \mathrm{v})$ or $\mathrm{NaHCO}_{3}(0.1 \%, \mathrm{w} / \mathrm{v})$ ] or photoheterotrophically [anaerobically in the light, with methanol $(0.1 \%$, w/v), yeast extract $(0.3 \%, \mathrm{w} / \mathrm{v})$, tryptone $(0.3 \%, \mathrm{w} / \mathrm{v})$, sodium acetate $(0.3 \%, w / v)$ or sodium pyruvate $(0.3 \%, w / v)]$. An internal membrane system and carotenoids were absent, and no invivo absorption peaks were detected. Furthermore, no puf gene products were detected from the PCR amplification of genomic DNA of strain A1 $-9^{\mathrm{T}}$ using all the primer pairs described by Nagashima et al. (1997); meanwhile, several puf gene-specific products were amplified from genomic DNA of Rba. capsulatus JCM $21090^{\mathrm{T}}$ (not shown). All of these results indicated that strain $\mathrm{A} 1-9^{\mathrm{T}}$ was not a member of the genus Rhodobacter.

Genomic DNA extraction, PCR and sequencing of the $16 \mathrm{~S}$ rRNA gene were carried out according to the procedures given by Kim et al. (1998). The sequence of the amplified fragment was determined by direct sequencing and compared with available $16 \mathrm{~S}$ rRNA gene sequences in GenBank using the BLAST program (Altschul et al., 1990). Multiple alignment with closely related sequences was performed by using the CLUSTAL_X program (Thompson et al., 1994). Ambiguous and unalignable bases were omitted manually and then the phylogenetic tree was reconstructed from an evolutionary distance matrix calculated using the neighbour-joining method in the MEGA program (version 3.1; Kumar et al., 2004). Phylogenetic analyses based on $16 \mathrm{~S}$ rRNA gene sequences revealed that strain $\mathrm{A} 1-9^{\mathrm{T}}$ was closely related to species of the genera Rhodobacter (95.5-90.7\% sequence similarity), Catellibacterium (94.2\%), Haematobacter (93.2\%), Paracoccus (93.5-91.1\%) and Rhodovulum (91.4-90.2\%). It formed a deep phyletic cluster with C. nectariphilum AST4 ${ }^{\mathrm{T}}$ within the family Rhodobacteraceae (Fig. 1).

For fatty acid methyl ester analysis, cell mass of strain A1$9^{\mathrm{T}}$ was obtained from NPB agar (Tanaka et al., 2004) after cultivation for 3 days at $30{ }^{\circ} \mathrm{C}$. Cellular fatty acids were extracted, methylated and analysed by using the Sherlock
Microbial Identification System (MIDI) according to the manufacturer's instructions. Strain $\mathrm{A} 1-9^{\mathrm{T}}$ had a fatty acid profile similar to that of C. nectariphilum JCM $11959^{\mathrm{T}}$ (Table 2). The dominant fatty acid was $\mathrm{C}_{18: 1} \omega 7 c$ for both strains. However, $\mathrm{C}_{10: 0} 3-\mathrm{OH}(15.3 \%)$ was another major fatty acid for strain A1-9 ${ }^{\mathrm{T}}$. Furthermore, in the fatty acid composition, A1-9 ${ }^{\mathrm{T}}$ differed from C. nectariphilum JCM $11959^{\mathrm{T}}$ in the presence of small amounts of some fatty acids such as 11-methyl $\mathrm{C}_{18: 1} \omega 7 \mathrm{c}$ and 10-methyl $\mathrm{C}_{19: 0}$ and the absence of some minor fatty acids such as $\mathrm{C}_{19: 0}$ cyclo $\omega 8 c$ and summed feature 3. Isoprenoid quinones were extracted and analysed as described by Komagata \& Suzuki (1987). Strain A1-9 ${ }^{\mathrm{T}}$ contained ubiquinone Q-10 as the sole respiratory quinone. The DNA $\mathrm{G}+\mathrm{C}$ content was determined by the thermal denaturation method (Sly et al., 1986) and DNA from Escherichia coli K-12 was used as a control. The DNA $\mathrm{G}+\mathrm{C}$ content of strain $A 1-9^{\mathrm{T}}$ was $64.4 \mathrm{~mol} \%$.

Although strain A1- $9^{\mathrm{T}}$ showed the highest $16 \mathrm{~S}$ rRNA gene sequence similarity to Rba. changlensis $\mathrm{JA} 139^{\mathrm{T}}(95.5 \%)$, it could be clearly distinguished from members of the genus Rhodobacter by the absence of photosynthetic activity and carotenoids, indicating that it is not a member of the genus Rhodobacter. Strain A1-9 ${ }^{\mathrm{T}}$ shared several important characteristics with the genus Catellibacterium, as shown in Table 1, such as strictly aerobic growth, with no growth under anaerobic conditions by fermentation, nitrate reduction or phototrophy, the presence of oxidase and catalase activities and absence of nitrate reduction, indole production, urease activity and hydrolysis of gelatin and arginine, indicating that it is likely to be a member of the genus Catellibacterium. However, several properties, including nutrient requirements for growth, motility, growth temperature and $\mathrm{pH}$ ranges, $\mathrm{NaCl}$ tolerance, utilization of several carbon sources and activities of some enzymes (Table 1) differentiate strain $\mathrm{A} 1-\mathrm{9}^{\mathrm{T}}$ from $C$. nectariphilum JCM $11959^{\mathrm{T}}$.

On the basis of our phenotypic, chemotaxonomic and phylogenetic data, strain $\mathrm{A} 1-9^{\mathrm{T}}$ is considered to represent a novel species of the genus Catellibacterium, for which we propose the name Catellibacterium aquatile sp. nov.

\section{Emended description of the genus Catellibacterium Tanaka et al. 2004}

The formal description given by Tanaka et al. (2004) remains correct except that some species are motile.

\section{Description of Catellibacterium aquatile sp. nov.}

Catellibacterium aquatile (a.qua'ti.le. L. neut. adj. aquatile living in water).

Exhibits the following properties in addition to those given in the genus description (Tanaka et al., 2004). Cells are 0.5$0.6 \mu \mathrm{m}$ wide and $1.0-1.6 \mu \mathrm{m}$ long. Grows at $10-40{ }^{\circ} \mathrm{C}$ and $\mathrm{pH}$ 5.5-9.0, with optimal growth at $25-30^{\circ} \mathrm{C}$ and $\mathrm{pH} 6.0-$ 6.5. $\mathrm{NaCl}$ is not required for growth; tolerates up to $1.0 \%$ 


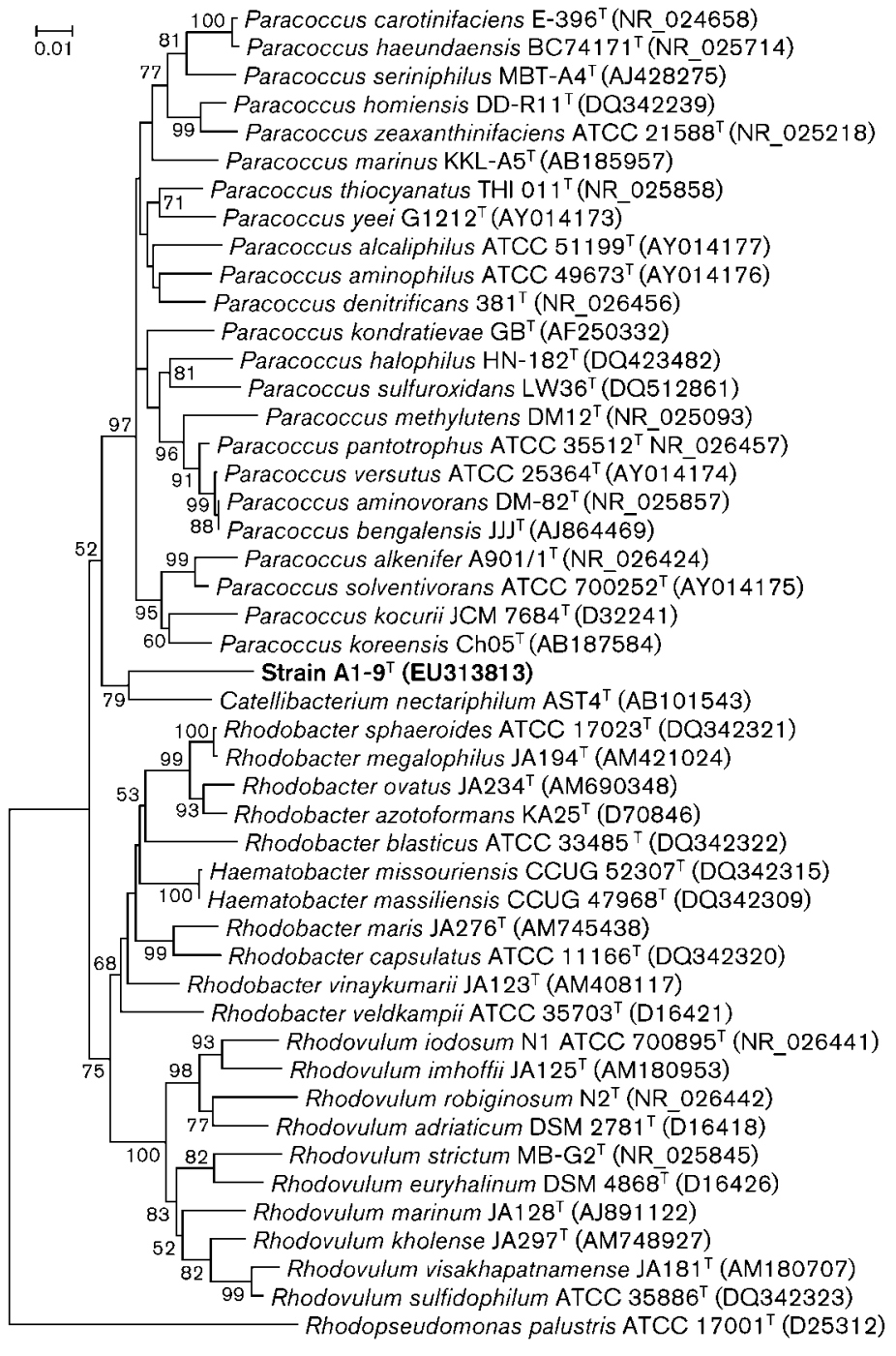

Fig. 1. Neighbour-joining tree based on $16 \mathrm{~S}$ rRNA gene sequences showing the phylogenetic position of strain $A 1-9^{\top}$ and representatives of some other related taxa. Bootstrap values (expressed as percentages of 1000 replications) $>50 \%$ are shown at branch points. The sequence of Rhodopseudomonas palustris ATCC $17001^{\top}$ was used as an outgroup. Bar, 0.01 substitutions per nucleotide position.
Table 2. Comparison of cellular fatty acid contents (\%) of strain $\mathrm{A} 1-9^{\top}$ and C. nectariphilum JCM $11959^{\top}$

Data are from this study. Both strains were grown on NPB agar for 3 days at $30{ }^{\circ}$ C.,$-<1 \%$ or not detected.

\begin{tabular}{|lcc|}
\hline Fatty acid & A1-9 & $\begin{array}{c}\text { C. nectariphilum } \mathbf{~ J C M} \\
\mathbf{1 1 9 5 9}^{\mathbf{T}}\end{array}$ \\
\hline $\mathrm{C}_{10: 0} 3-\mathrm{OH}$ & 15.3 & 6.0 \\
$\mathrm{C}_{16: 0}$ & 1.1 & 1.6 \\
$\mathrm{C}_{18: 1} \omega 7 c$ & 70.0 & 75.7 \\
$\mathrm{C}_{18: 0}$ & 4.7 & 2.7 \\
$11-$ Methyl $\mathrm{C}_{18: 1} \omega 7 c$ & 2.4 & - \\
$10-$ Methyl $\mathrm{C}_{19: 0}$ & 1.2 & - \\
$\mathrm{C}_{18: 0} 3-\mathrm{OH}$ & 1.6 & 2.8 \\
$\mathrm{C}_{19: 0}$ cyclo $\omega 8 c$ & - & 5.5 \\
Summed feature $3 *$ & - & 1.2 \\
\hline
\end{tabular}

* Summed features are groups of two or three fatty acids that cannot be separated by GLC using the MIDI system. Summed feature 3 contained iso- $\mathrm{C}_{15: 0} 2-\mathrm{OH}$ and/or $\mathrm{C}_{16: 1} \omega 7 c$. (w/v) NaCl. Colonies were transparent, non-pigmented, smooth, circular and convex, 1-2 $\mathrm{mm}$ in diameter after 2 days of incubation on YP agar. Positive for $\mathrm{H}_{2} \mathrm{~S}$ production and hydrolysis of aesculin, L-tyrosine and Tweens 20 and 80; negative for nitrate reduction, indole production, arginine dihydrolase and urease activity and hydrolysis of gelatin, casein, starch and Tweens 40 and 60 . In the API ZYM system, strongly positive enzyme activity is observed for acid phosphatase and positive activity is observed for esterase (C4), esterase lipase (C8), leucine arylamidase, $\beta$-galactosidase, $\alpha$-glucosidase and $\beta$ glucosidase; no activity is observed for alkaline phosphatase, lipase (C14), valine arylamidase, cystine arylamidase, trypsin, chymotrypsin, naphthol-AS-BI-phosphohydrolase, $\alpha$-galactosidase, $\beta$-glucuronidase, $N$-acetyl- $\beta$-glucosaminidase, $\alpha$-mannosidase or $\alpha$-fucosidase. Utilizes L-arabinose, monomethyl succinate, $\beta$-hydroxybutyrate, DL-lactate and L-alanyl glycine; does not utilize other carbohydrates in the Biolog GN2 test. The DNA G $+\mathrm{C}$ content of the type strain is $64.4 \mathrm{~mol} \%\left(T_{\mathrm{m}}\right)$. Sensitive to $(\mu \mathrm{g}$ per disc unless indicated) vancomycin (30), gentamicin (10), carbenicillin 
(100), streptomycin (10), tetracycline (30), kanamycin (30), ampicillin (10), erythromycin (15), novobiocin (5), neomycin (30), chloramphenicol (30), ciprofloxacin (5), norfloxacin (10), rifampicin (5) and polymyxin B (300 IU).

The type strain, A1-9 $9^{\mathrm{T}} \quad\left(=\mathrm{CGMCC} 1.7029^{\mathrm{T}}=\mathrm{NBRC}\right.$ $104254^{\mathrm{T}}$ ), was isolated from fresh water of Daqing reservoir, north-east China.

\section{Acknowledgements}

This work was supported by grants from the High-Tech Development Program of China (863 program no. 2006AA06Z316) and the Knowledge Innovation Program of the Chinese Academy of Sciences (no. KSCS2-YW-G-055-01)

\section{References}

Altschul, S. F., Gish, W., Miller, W., Myers, E. W. \& Lipman, D. J. (1990). Basic local alignment search tool. J Mol Biol 215, 403-410.

Anil Kumar, P., Aparna, P., Srinivas, T. N. R., Sasikala, Ch. \& Ramana, Ch. V. (2008). Rhodovulum kholense sp. nov. Int J Syst Evol Microbiol 58, 1723-1726.

Arunasri, K., Venkata Ramana, V., Spröer, C., Sasikala, Ch. \& Ramana, Ch. V. (2008). Rhodobacter megalophilus sp. nov., a phototroph from the Indian Himalayas possessing a wide temperature range for growth. Int J Syst Evol Microbiol 58, 1792-1796.

Boldareva, E. N., Akimov, V. N., Boychenko, V. A., Stadnichuk, I. N., Moskalenko, A. A., Makhneva, Z. K. \& Gorlenko, V. M. (2008). Rhodobaca barguzinensis sp. nov., a new alkaliphilic purple nonsulfur bacterium isolated from a soda lake of the Barguzin Valley (Buryat Republic, Eastern Siberia). Mikrobiologiia 77, 241-254 (in Russian).

Bruns, A., Rohde, M. \& Berthe-Corti, L. (2001). Muricauda ruestringensis gen. nov., sp. nov., a facultatively anaerobic, appendaged bacterium from German North Sea intertidal sediment. Int $J$ Syst Evol Microbiol 51, 1997-2006.

Chakravarthy, S. K., Sucharitha, K., Sasikala, C. \& Ramana, C. V. (2009). Rhodovulum lacipunicei sp. nov., an obligate sulfide-demanding phototrophic alphaproteobacterium isolated from a purple pond in India. Int J Syst Evol Microbiol 59, 1615-1619.

Cowan, S. T. \& Steel, K. J. (1965). Manual for the Identification of Medical Bacteria. London: Cambridge University Press.

Dong, X.-Z. \& Cai, M.-Y. (editors) (2001). Determination of biochemical properties. In Manual for the Systematic Identification of General Bacteria, pp. 370-398. Beijing: Science Press (in Chinese).

Gerhardt, P., Murray, R. G. E., Wood, W. A. \& Krieg, N. R. (editors) (1994). Methods for General and Molecular Bacteriology. Washington, DC: American Society for Microbiology.

Imhoff, J. F. \& Caumette, P. (2004). Recommended standards for the description of new species of anoxygenic phototrophic bacteria. Int $J$ Syst Evol Microbiol 54, 1415-1421.

Kim, S. B., Falconer, C., Williams, E. \& Goodfellow, M. (1998). Streptomyces thermocarboxydovorans $\mathrm{sp}$. nov. and Streptomyces thermocarboxydus sp. nov., two moderately thermophilic carboxydotrophic species from soil. Int J Syst Bacteriol 48, 59-68.

Komagata, K. \& Suzuki, K. (1987). Lipid and cell-wall analysis in bacterial systematics. Methods Microbiol 19, 161-207.

Kumar, S., Tamura, K. \& Nei, M. (2004). MEGA 3: integrated software for molecular evolutionary genetics analysis and sequence alignment. Brief Bioinform 5, 150-163.

Liu, Z.-P., Wang, B.-J., Liu, X.-Y., Dai, X., Liu, Y.-H. \& Liu, S.-J. (2008). Paracoccus halophilus sp. nov., isolated from marine sediment of the South China Sea, China, and emended description of genus Paracoccus Davis 1969. Int J Syst Evol Microbiol 58, 257-261.

Nagashima, K. V. P., Hiraishi, A., Shimada, K. \& Matsuura, K. (1997). Horizontal transfer of genes coding for the photosynthetic reaction centers of purple bacteria. J Mol Evol 45, 131-136.

Pfennig, N. \& Trüper, H. G. (1974). The phototrophic bacteria. In Bergey's Manual of Determinative Bacteriology, 8th edn, pp. 24-75. Edited by R. E. Buchanan \& N. E. Gibbons. Baltimore: Williams \& Wilkins.

Roh, S. W., Nam, Y.-D., Chang, H.-W., Kim, K.-H., Kim, M.-S., Shin, K.-S., Yoon, J.-H., Oh, H.-M. \& Bae, J.-W. (2009). Paracoccus aestuarii sp. nov., isolated from tidal flat sediment. Int J Syst Evol Microbiol 59, 790-794.

Sly, L. I., Blackall, L. L., Kraat, P. C., Tian-Shen, T. \& Sangkhobol, V. (1986). The use of second derivative plots for the determination of mol\% guanine plus cytosine of DNA by the thermal denaturation method. J Microbiol Methods 5, 139-156.

Srinivas, T. N. R., Anil Kumar, P., Sasikala, Ch., Spröer, C. \& Ramana, Ch. V. (2008). Rhodobacter ovatus sp. nov., a phototrophic alphaproteobacterium isolated from a polluted pond. Int J Syst Evol Microbiol 58, 1379-1383.

Tanaka, Y., Hanada, S., Manome, A., Tsuchida, T., Kurane, R., Nakamura, K. \& Kamagata, Y. (2004). Catellibacterium nectariphilum gen. nov., sp. nov., which requires a diffusible compound from a strain related to the genus Sphingomonas for vigorous growth. Int $J$ Syst Evol Microbiol 54, 955-959.

Thompson, J. D., Higgins, D. G. \& Gibson, T. J. (1994). CLUSTAL W: improving the sensitivity of progressive multiple sequence alignment through sequence weighting, position-specific gap penalties and weight matrix choice. Nucleic Acids Res 22, 4673-4680.

Venkata Ramana, V., Sasikala, Ch. \& Ramana, Ch. V. (2008). Rhodobacter maris sp. nov., a phototrophic alphaproteobacterium isolated from a marine habitat of India. Int J Syst Evol Microbiol 58, 1719-1722.

Venkata Ramana, V., Anil Kumar, P., Srinivas, T. N. R., Sasikala, Ch. \& Ramana, Ch. V. (2009). Rhodobacter aestuarii sp. nov., a phototrophic alphaproteobacterium isolated from an estuarine environment. Int $J$ Syst Evol Microbiol 59, 1133-1136.

Wang, Y., Tang, S.-K., Lou, K., Mao, P.-H., Jin, X., Jiang, C.-L., Xu, L.-H. \& Li, W.-J. (2009). Paracoccus saliphilus sp. nov., a novel halophilic bacterium isolated from a salt lake. Int J Syst Evol Microbiol 59, 19241928.

Yoon, J.-H., Yeo, S.-H. \& Oh, T.-K. (2004). Hongiella marincola sp. nov., isolated from sea water of the East Sea in Korea. Int J Syst Evol Microbiol 54, 1845-1848. 